\title{
Controls of Land Use and the River Continuum Concept on Dissolved Organic Matter Composition in an Anthropogenically Disturbed Subtropical Watershed
}

\author{
Jesse Alan Roebuck, Jr., ${ }^{* \dagger, \S(0)}$ Michael Seidel, ${ }^{\ddagger}{ }^{\ddagger}$ Thorsten Dittmar, ${ }^{\ddagger} \perp$ and Rudolf Jaffe ${ }^{\dagger}$ \\ ${ }^{\dagger}$ Southeast Environmental Research Center and Department of Chemistry and Biochemistry, Florida International University, \\ Miami, Florida 33199, United States \\ ${ }^{\ddagger}$ Research Group for Marine Geochemistry, Institute for Chemistry and Biology of the Marine Environment (ICBM), University of \\ Oldenburg, D-26129 Oldenburg, Germany \\ ${ }^{\perp}$ Helmholtz Institute for Functional Marine Diversity, University of Oldenburg (HIFMB), D-26129 Oldenburg, Germany
}

\section{Supporting Information}

\begin{abstract}
About $250 \mathrm{Tg}$ of dissolved organic carbon are annually transported from inland waters to coastal systems making rivers a critical link between terrestrial and ocean carbon pools. During transport through fluvial systems, various biogeochemical processes selectively remove or transform labile material, effectively altering the composition of dissolved organic matter (DOM) exported to the ocean. The river continuum concept (RCC) has been historically used as a model to predict the fate and quality of organic matter along a river continuum. However, the conversion of natural landscapes for urban and agricultural practices can also alter the sources and quality of DOM exported from fluvial systems, and the RCC may be significantly limited in predicting DOM quality in anthropogenically impacted watersheds. Here, we studied DOM dynamics in the Altamaha River watershed in Georgia, USA, a fluvial system where headwater streams are highly impacted by anthropogenic activities. The primary goal of this study was to quantitatively assess the importance of both the RCC and land use as environmental drivers controlling DOM composition. Land use was a stronger predictor of spatial variation $(\sim 50 \%)$ in DOM composition defined by both excitation-emission matrix-parallel factor analysis (EEM-PARAFAC) and ultrahigh-resolution mass spectrometry. This is compared to an $8 \%$ explained variability that can be attributed to the RCC. This study highlights the importance of incorporating land use among other controls into the RCC to better predict the fate and quality of DOM exported from terrestrial to coastal systems.
\end{abstract}

\section{INTRODUCTION}

Dissolved organic matter (DOM) contains the largest pool of exchangeable organic carbon transported throughout terrestrial systems, and the contribution of dissolved organic carbon (DOC) exported from rivers to coastal systems is estimated at roughly $250 \mathrm{Tg}_{\text {year }}{ }^{-1}$. The role of DOM in aquatic systems is quite diverse but is considered critical for riverine health and ecosystem functions. For instance, chromophoric DOM (CDOM) is a light attenuator that can both regulate primary production $^{2}$ and protect aquatic organisms from harmful radiation. ${ }^{3}$ In addition, DOM serves as a primary energy source for microbial heterotrophs in fueling ecosystem respiration ${ }^{4,5}$ and also alters the solubility and transport of metals and organic pollutants. ${ }^{6}$ As such, DOM is also a significant source of $\mathrm{CO}_{2}$ evasion from aquatic systems ${ }^{5,7,8}$ and thus a critical component within the global carbon cycle.

While DOM exported from rivers has been most prominently linked to terrestrial sources (allochthonous), such as vascular polyphenols referred to as humic substances generated from the decomposed plant material, ${ }^{9,10}$ it may also be derived from in-stream sources (autochthonous). ${ }^{11}$ The composition of DOM is a leading factor in its general reactivity. ${ }^{12}$ During fluvial transport, DOM may be exposed to a variety of in-stream biogeochemical processes that may ultimately alter its composition and fate. Such processes may include photodegradation, ${ }^{13}$ flocculation and interaction with metals, $^{14-17}$ and microbial respiration. ${ }^{5,18}$ As DOM has become increasingly linked with terrestrial ecosystem processes and its role in global carbon cycling has become more evident, there is an increasing need for a better understanding of riverine dynamics that control the fate and transport of DOM in fluvial systems.

The river continuum concept (RCC) was established nearly four decades ago providing a general paradigm for fluvial ecosystem functions and predicting systematic biological responses along a river continuum. ${ }^{19}$ The original hypothesis states that detrital sources of organic matter vary with increasing stream order from a heterotrophic environment (stream order 1-3) to autotrophic (stream order 4-6) followed by a return to a heterotrophic state (stream orders 7 and above). The RCC further suggests that the molecular

Received: July 30, 2019

Revised: November 1, 2019

Accepted: November 19, 2019

Published: November 19, 2019 
chemical diversity of DOM is highest in the upper headwaters where contributions are primarily derived from terrestrial sources. With longitudinal succession, labile components are selectively removed through various biogeochemical pathways, and sources of DOM shift primarily to an autochthonous signature as light availability increases (less canopy cover, wider rivers) and photosynthesis exceeds ecosystem respiration. This generally leads to a decrease in DOM molecular diversity with increasing stream order. ${ }^{19-21}$ This pattern was found to be accompanied by an increasingly refractory pool of DOM along the river continuum, ${ }^{22,23}$ likely the result of various degradation processes and a disconnect between the terrestrial and aquatic environments downstream. ${ }^{21}$ With modern advancements in DOM characterization, others have generally confirmed the original RCC hypothesis by noting a higher number of molecular formulae (as detected with ultrahigh-resolution mass spectrometry) in lower stream orders $^{20}$ and homogenization of DOM fluorescence with longitudinal transport downstream. ${ }^{24}$ However, while stream order has been used previously as a proxy to show clear processing and degradation of DOM along the river continuum, ${ }^{25,26}$ some cases have shown that stream order does little in predicting DOM dynamics in fluvial systems. ${ }^{27}$ Since its inception, many limitations to the RCC have been highlighted and adaptations to this paradigm have been introduced with efforts to acknowledge a variety of anthropogenic and hydrological stressors on aquatic systems such as serial discontinuity, ${ }^{28}$ the influence of floodplain sources, ${ }^{29}$ and the impacts of seasonally high discharge stormdriven events. ${ }^{30}$ However, DOM composition has also been very closely linked with watershed land use, ${ }^{31-35}$ a parameter not considered in the RCC as it was originally developed for natural, undisturbed systems.

Globally, watershed activity is rapidly changing as urbanization continues to increase in response to population growth, and now, more than $40 \%$ of Earth's landmass has been developed for agricultural purposes. ${ }^{36}$ The DOM exported from headwater streams has routinely been linked to the presence of natural covers where allochthonous sources dominate contributions to DOM export. ${ }^{37}$ However, headwater urban streams are increasingly decoupled hydrologically from riparian zones as channelization and drainage networks are engineered, thus greatly altering these streams from their natural states. ${ }^{38,39}$ In response, storm drains, ditches, and leaky sewers and septic systems increase both carbon and nutrient loads while also increasing the transport of pollutants downstream. $^{40}$ Furthermore, the high export of nutrients from both urban and agricultural watersheds fuels autotrophic activity in streams leading to significant source-related shifts in DOM composition (e.g., increased autochthonous- and/or microbial-derived signatures). ${ }^{35,41}$ Thus, as DOM sources and composition have been extensively linked to watershed land cover, there is a need to further link the controls of land use with classic paradigms such as the RCC to better predict the fate and quality of DOM exported from fluvial systems with future climate and land use change scenarios.

In our study, we are answering the question to what extent the RCC still can be effective to understand fluvial DOM transport in watersheds with significant anthropogenic disturbance. The Altamaha River, which is located entirely within the state of Georgia, USA, is a prime example in which an effort to understand ecosystem controls on DOM sources and composition as predicted by the RCC might become limited due to a high degree of anthropogenic activity, particularly in the upper watershed. In this study, the Altamaha River was extensively sampled from headwaters to mouth over a gradient of low to high stream orders with a high degree of variability in land cover. The DOM was characterized using ultrahigh-resolution mass spectrometry and fluorescence spectroscopy. Multivariate statistical approaches were then used to assess the relative importance of both land use and the RCC (stream order) as environmental drivers of the DOM composition and molecular diversity in the Altamaha River. We hypothesized that land use would be a strong predictor of DOM dynamics throughout the watershed, shifting the DOM composition to a more autochthonous and labile signature with increasing anthropization. With the strongest anthropogenic activity in the upper watershed, we further hypothesized that labile DOM would be preferentially removed during fluvial transport in congruence with the original predictions of the RCC. Our results highlight the need to consider land use with traditional paradigms in predicting the fate and quality of DOM exported to coastal systems.

\section{METHODS}

2.1. Sample Locations and Collection. With a drainage basin of roughly $36000 \mathrm{~km}^{2}$, the Altamaha River drains primarily by means of the Ocmulgee River and Oconee River tributaries (Figures 1 and S1), each developing within the Georgia Piedmont Region at the foothills of Appalachia. The headwaters of each of these tributaries drain from highly anthropogenically impacted areas, with the Ocmulgee River draining primarily from the Atlanta Metropolitan Area and the Oconee River draining areas with enhanced agricultural activity (soy, hay, poultry; Figures 1 and S1). ${ }^{42}$ Nutrient exports are highest in the upper watershed as would be expected in anthropogenically impacted systems and decrease downstream. $^{42}$

A total of 42 samples were collected throughout the Altamaha River watershed over a 5 day period in May 2016 at the onset of a hydrological dry period. Samples were collected primarily within the Oconee River tributary, representing the spatially longest possible transect within this system. A single sample was also collected at the mouth of each of the other three primary tributaries to the Altamaha River (Ocmulgee River, Little Ocmulgee River, and Ohoopee River; Figures 1 and S1). Sample locations were selected with a diverse set of land use activity including both natural and anthropogenic disturbances while also representing a gradient of low-order headwater streams to larger, high-order rivers downstream (Figures 1 and S1). Samples were classified and assigned to a stream order group based on the Strahler classification system, ${ }^{43}$ which includes low-order small streams (stream order $1-3, n=14$ ) and medium-order small rivers (stream order $4-6, n=11$ ) in the upper watershed, and highorder large rivers (stream order $>6, n=11$ ) in the lower watershed.

When possible, $1 \mathrm{~L}$ samples were collected directly along the riverbanks in actively flowing sections of the rivers and placed into clean high-density polyethylene (HDPE) bottles. Otherwise, samples were collected by dispensing a 5 gal bucket from a bridge followed by transfer to a clean HDPE bottle. This bucket was prerinsed three times with river water prior to sample collection. In all cases, HDPE bottles were pretreated with $2 \mathrm{M} \mathrm{HCl}$ and $2 \mathrm{M} \mathrm{NaOH}$ for $24 \mathrm{~h}$ each and rinsed with ultrapure water. These bottles were also prerinsed three times 


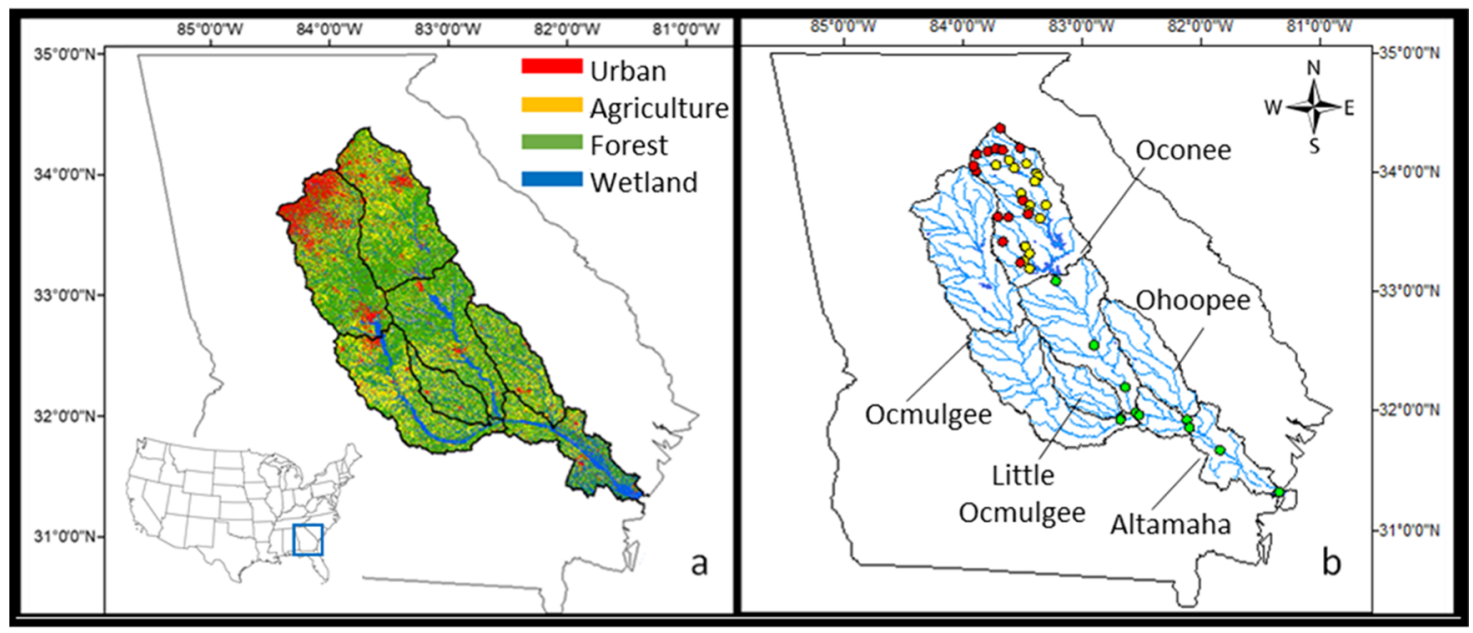

Figure 1. (a) Map of land-use characteristics in the Altamaha River (inset includes a map of United States with Georgia highlighted in blue) and (b) map of sample locations and stream order classification. Red, yellow, and green circles depict small, medium, and high stream orders, respectively.

with sample water prior to the final collection. Samples were stored in the dark on ice during transport back to the laboratory.

All samples were filtered on the same day of collection (generally less than $12 \mathrm{~h}$ ) through a precombusted $\left(500^{\circ} \mathrm{C}, 5\right.$ h) $0.7 \mu \mathrm{m}$ Whatman glass fiber filter (GFF). DOM was further extracted from river samples using a solid-phase extraction technique previously described by Dittmar et al. ${ }^{44}$ Briefly, Agilent Bond Elut PPL ( $1 \mathrm{~g})$ cartridges were conditioned with methanol followed by ultrapure water $(\mathrm{pH} 2)$. Roughly $1 \mathrm{~L}$ of sample was loaded onto the cartridge followed by another rinse with ultrapure water $(\mathrm{pH} 2)$. The cartridges were then dried under a stream of $\mathrm{N}_{2}$ gas followed by elution of DOM in 10 $\mathrm{mL}$ of methanol and stored at $-20{ }^{\circ} \mathrm{C}$ until further analysis. The extraction efficiencies were determined as DOC in methanol extract divided by bulk DOC concentrations of the original samples. DOC in methanol extracts was determined by drying an aliquot of the extract and redissolving it in ultrapure water. The extraction efficiency for these samples was $73 \pm 8 \%$.

2.2. Water Quality Analysis. Surface water samples were collected and filtered on location for DOC and total dissolved nitrogen (TDN, including both inorganic and organic forms of nitrogen) analyses. Samples were filtered through precombusted $0.7 \mu \mathrm{m}$ GFF filters and stored at $4{ }^{\circ} \mathrm{C}$ in the dark until further analysis. Samples for DOC determinations were acidified to $\mathrm{pH} 2$ with concentrated hydrochloric acid and purged to remove inorganic carbon followed by analysis on a Shimadzu TOC-V CSH total organic carbon analyzer. TOC quality control standards from ERA (Demand, WasteWarR, Lot\#516) were measured and determined to be within $0.3 \%$ of the reported value. The TDN was analyzed with the ASTM D5176-91 protocol (doi: 10.1520/D5176-91R03), which is the "Standard Test Method for Total Chemically Bound Nitrogen in Water by Pyrolysis and Chemiluminescence Detection". Turbidity was measured on site with a LaMotte 2020 turbidimeter.

2.3. Optical Properties and Parallel Factor (PARAFAC) Analysis. UV absorbance scans and fluorescence excitationemission matrices (EEMs) were collected simultaneously using an Aqualog (Horiba Scientific) equipped with a $150 \mathrm{~W}$ continuous output xenon lamp. Fluorescence spectra were corrected for inner filter effects ${ }^{45}$ and normalized to Raman scatter units. The EEMs were further characterized by parallel factor (PARAFAC) analysis as observed in Figure S2. There were no outliers removed, and the model was split-halfvalidated using the DrEEMs tool box ${ }^{46}$ in MATLAB R2015b, and PARAFAC components were compared with those logged within the OpenFluor database. To minimize concentration effects, PARAFAC components are reported in relative abundance for each sample.

2.4. Ultrahigh-Resolution Mass Spectrometry. Methanol extracts containing isolated DOM were diluted in 1:1 methanol/water to a final concentration of $5 \mathrm{mg} \mathrm{C} \mathrm{L} \mathrm{L}^{-1}$. Samples were analyzed by ultrahigh-resolution mass spectrometry as described by Seidel et al. ${ }^{47}$ using a solariX XR Fourier transform ion cyclotron resonance mass spectrometer (FTICR-MS, Bruker Daltonik GmbH, Bremen, Germany) connected to a $15 \mathrm{~T}$ superconducting magnet. Samples were infused into the electrospray source (Apollo II ion source, Bruker Daltonik $\mathrm{GmbH}$, Bremen, Germany) in negative mode at $2 \mu \mathrm{L} \mathrm{min}{ }^{-1}$. Two hundred scans were collected with a mass window from 150 to $2000 \mathrm{Da}$. Molecular formulae above the method detection limit ${ }^{48}$ were assigned under the following constraints: ${ }^{12} \mathrm{C}_{1-30}{ }^{1} \mathrm{H}_{1-200} \mathrm{O}_{1-50}{ }^{14} \mathrm{~N}_{0-4} \mathrm{~S}_{0-2} \mathrm{P}_{0-1}$. Molecular masses were removed for further analysis when detected in less than three samples. Samples were normalized to the sum of FTICR-MS signal intensities with a modified aromaticity index $\left(\mathrm{AI}_{\text {mod }}\right),{ }^{49,50}$ and intensity weighted molar ratios were calculated for each sample (Table S5). Molecular formulae were further categorized into molecular compound classes as described by Seidel et al. ${ }^{47}$ and are described as follows: (1) $\mathrm{AI}_{\text {mod }}>0.67,<15$ carbon atoms, (2) condensed aromatic compounds $\geq 15$ carbons, (3) condensed aromatic compounds with heteroatoms, (4) highly aromatic compounds including polyphenols, (5), highly unsaturated compounds, (6) unsaturated aliphatics, (7) saturated compounds with low $\mathrm{O} / \mathrm{C}$ ratios and with heteroatoms, (8) saturated compounds with high $\mathrm{O} /$ $\mathrm{C}$ ratios including carbohydrates, (9) saturated compounds with high $\mathrm{O} / \mathrm{C}$ and with heteroatoms, and (10) unsaturated aliphatic molecular formulae with nitrogen. Molecular compound classes are further described as their relative intensity weighted contributions to each sample (Table S7). While data for all 10 groups are provided, due to groups 2 (condensed polycyclic aromatics), 4 (highly aromatic com- 
pounds), 6 (unsaturated aliphatic), and 10 (unsaturated aliphatic with $\mathrm{N}$, which may include peptide degradation products) providing the strongest relationships to land use (Table 1), further discussion of FTICR-MS compound classes is primarily limited to these four groups.

2.5. Calculation of DOM Diversity Indices. Diversity measures along the Altamaha River continuum for this study were calculated using two unique diversity indices, which include (1) molecular complexity and (2) the functional molecular diversity. Molecular complexity is simply defined as the unique number of molecular formulae in a sample detected by an FTICR-MS measurement.

The functional diversity index $\left(F_{\mathrm{D}}\right)$ was initially developed to quantify the diversity of functions within an ecological community $^{51}$ and has been recently adapted for use in a chemical context for complex DOM mixtures. ${ }^{52,53}$ The $F_{D}$ applied to DOM is computed as a distance function using the average difference between any two molecular formulae with respect to a given chemical property (e.g., $m / z$, etc.) and can be interpreted under the assumption that molecular formulae that share similar chemical characteristics (and thus little average difference and low computed $F_{\mathrm{D}}$ ) will behave similarly in an ecological context. For example, photochemical degradation is highly selective for aromatic DOM compounds, which are typically represented by a high number of doublebond equivalents (DBE). ${ }^{54}$ Thus, the $F_{\mathrm{D}}$ of a sample computed based on DBE should decrease after photoirradiation as selective high DBE compounds are removed from the sample. The $F_{\mathrm{D}}$ is calculated following Mentges et al. ${ }^{52}$ below

$$
F_{\mathrm{D}}=\sum_{i=1}^{N-1} \sum_{j=i+1}^{N} p_{i} \cdot p_{j} \cdot\left|c_{i}-c_{j}\right|
$$

Here, $N$ is representative of the total number of molecular formulae detected in a sample, $c$ is the quantified chemical property for a given molecular formula, and $\left|c_{i}-c_{j}\right|$ is the measured difference for the specified chemical property for any pair of molecular formulae. The $F_{D}$ is further sum-normalized to signal intensity for the selected pair of molecular formulae $\left(p_{i}\right.$ and $\left.p_{j}\right)$. For this study, the $F_{\mathrm{D}}$ was calculated with mass-tocharge ratio $\left(F_{\mathrm{D}-m / z}\right)$ as an indicator of changes in molecular weight, double-bond equivalents $\left(F_{\mathrm{D}-\mathrm{DBE}}\right)$ as indicators of DOM aromaticity, and the number of nitrogen atoms $\left(F_{\mathrm{D}-\mathrm{N}}\right)$ as dissolved organic nitrogen typically represents a highly bioavailable fraction of DOM. ${ }^{55}$

2.6. Statistical Analysis and Land Use. A geographical information system (GIS) IMG data file containing Georgia land use information was obtained from the Georgia GIS Data Clearinghouse, which was originally provided by the National Resources Spatial Analysis Laboratory, University of Georgia. The initial 13 land use types were condensed to four major categories (urban, agriculture, forest, and wetlands), and relative contributions of each land use type were calculated in ArcMap version 10.3. Agriculture was defined as the combined area of croplands and pastures, whereas urbanization was largely defined as areas with high population density (e.g., the area occupied by single and multifamily dwellings, parks and recreation, campus-like institutions) and transportation (e.g., roads, railroads, and airports). Forested land use includes areas occupied by $>75 \%$ deciduous and/or evergreen forests, and wetlands were defined as containing cypress gum, evergreen and deciduous wetlands, and depressional and shrub wetlands. Land use at each sample location was derived as a function of the entire upstream catchment area.

JMP version 12.0 was primarily used for statistical applications. One-way analysis of variance (ANOVA) followed by Tukey's honest significance difference (HSD) test was used to assess the variability and significance among variables distributed with respect to stream order. Percent urban land use and \%C2 were log-normalized to meet assumptions of a normal distribution, and the log-normalized values were used in all linear statistical applications discussed below. Pearson's product-moment correlation coefficient $(r)$ was further used to assess the overall significance of a relationship between any two parameters. The vegan package ${ }^{56}$ within the $\mathrm{R}$ statistical platform ${ }^{57}$ was used to calculate functional diversity indices and to perform a redundancy analysis (RDA) to assess the spatial variability in DOM composition as a function of both land use and stream order. For the RDA, PARAFAC and FTICR-MS data were constrained on the $y$-matrices with land use and stream order constrained to the $x$-matrices (predictor variables). The models were tested with 999 permutations, and they were significant at $p<0.001$.

\section{RESULTS}

Stream and river samples were categorized based on the Strahler stream order classification system and characterized by FTICR-MS and EEM-PARAFAC. The total number of molecular formulae detected by FTICR-MS across this Altamaha River dataset was $8200 \pm 800$. There was no significant difference $(p>0.05$, ANOVA) between small ( 8300 $\pm 600)$, medium $(8100 \pm 800)$, and large $(8200 \pm 800)$ stream orders. The $F_{\mathrm{D}}$, however, varied among stream order. The $F_{\mathrm{D}-m / z}$ was $2.20 \pm 0.01$ for small stream orders, $2.22 \pm$ 0.01 for medium stream orders, and $2.32 \pm 0.02$ for large stream orders. The $F_{\mathrm{D}-\mathrm{DBE}}$ was $1.78 \pm 0.01$ for small stream orders, $1.76 \pm 0.01$ for medium stream orders, and $1.88 \pm 0.01$ for large stream orders. Finally, the $F_{\mathrm{D}-\mathrm{N}}$ was $(0.207 \pm 0.005)$ for small stream orders, $0.216 \pm 0.005$ for medium stream orders, and $0.166 \pm 0.007$ for large stream orders. In all cases of $F_{\mathrm{D}}$, the larger stream order was significantly different from the small and medium stream orders $(p<0.05$, ANOVA, Tukey's HSD); however, the small and medium stream orders could not be distinguished from each other $(p>0.05$, ANOVA, Tukey's HSD).

Displaying similar patterns of $F_{\mathrm{D}}$, the relative abundance of FTICR-MS compound classes and the relative distribution of EEM-PARAFAC components varied among stream order. The relative abundance of FTICR-MS polycondensed aromatic compounds (group 2) and highly aromatic compounds (group 4) was $1.9 \pm 0.1$ and $15.4 \pm 0.4 \%$ for small stream orders, $1.8 \pm 0.1$ and $15.7 \pm 0.4 \%$ for medium stream orders, and $3.1 \pm 0.2$ and $18.2 \pm 0.4 \%$ for large stream orders, respectively. For unsaturated aliphatic compounds (group 6) and unsaturated aliphatic compounds containing nitrogen (group 10), the relative abundance was $9.9 \pm 0.4$ and $0.67 \pm 0.04 \%$ for small stream orders, $8.8 \pm 0.4$ and $0.61 \pm$ $0.04 \%$ for medium stream orders, and $6.0 \pm 0.5$ and $0.30 \pm$ $0.05 \%$ for large stream orders, respectively. For EEMPARAFAC, the relative contributions of terrestrial humic-like components C1, C2, and C4 averaged $33.3 \pm 0.5,24.6 \pm 0.05$, and $4.8 \pm 0.7 \%$ for small stream orders, $34.1 \pm 0.05,25.3 \pm$ 0.05 , and $5.9 \pm 0.6 \%$ for medium stream orders, and $35.5 \pm$ $0.6,29.2 \pm 0.05$, and $11.0 \pm 0.8 \%$ for large stream orders, respectively. The relative contribution of microbial humic-like 
C3 and protein-like C5 averaged $18.7 \pm 0.5$ and $18.6 \pm 0.8 \%$ for small stream orders, $19.2 \pm 0.4$ and $15.5 \pm 0.7 \%$ for medium stream orders, and $16.2 \pm 0.5$ and $8.0 \pm 0.9 \%$ for large stream orders, respectively. With the exception of $\mathrm{C} 1$, the aforementioned FTICR-MS groups and PARAFAC components were all significantly different for large stream orders compared to those of small and medium stream orders $(p<$ 0.05, ANOVA, Tukey's HSD); however, the small and medium stream orders were not significantly different $(p>0.05$, ANOVA, Tukey's HSD). There was no significant difference for $\mathrm{C} 1$ across all stream order groups $(p>0.05$, ANOVA, Tukey's HSD).

Watershed land cover was generally strongly correlated with EEM-PARAFAC components and FTICR-MS groups. For instance, wetlands were positively correlated with \%C1 $(r=$ $0.56, p<0.01), \% \mathrm{C} 2(r=0.78, p<0.01), \% \mathrm{C} 4(r=0.61, p<$ 0.01 ), polycondensed aromatic compounds (group 2, $r=0.74$, $p<0.01$ ), and highly aromatic compounds (group 4, $r=0.78$, $p<0.01)$. On the other hand, urban land use was positively correlated with protein-like component \%C5 $(r=0.50, p<$ 0.01 ), unsaturated aliphatic compounds (group 6, $r=0.36, p<$ $0.05)$, and unsaturated aliphatic compounds with nitrogen (group 10, $r=37, p<0.05$ ). Agricultural land use was positively correlated with microbial humic-like \%C3 $(r=0.36$, $p<0.05)$ and to unsaturated aliphatic compounds $(r=0.36, p$ $<0.05)$. Using redundancy analysis (RDA), 59\% of the variation in DOM composition described by EEM-PARAFAC could be explained as a function of both land use (52\%) and stream order (7\%). Similarly, 53\% of the DOM composition described by FTICR-MS could be explained by both land use $(45 \%)$ and stream order $(8 \%)$.

\section{DISCUSSION}

4.1. Controls of the RCC and Land Use on DOM Composition in the Upper Altamaha River. With efforts to isolate the controls of land use in conjunction with the RCC in the Altamaha River, samples were collected over a diverse gradient of land covers and further categorized by the Strahler stream order to coincide with the original RCC model. ${ }^{19}$ Surprisingly, there was no significant difference in molecular complexity (e.g., total number of molecular formulae detected by FTICR-MS) between small- and medium-order streams in the upper watershed (ANOVA, Tukey's HSD, $p>0.05$ ) as would be expected based on the original RCC. This is furthermore in contrast to a previous study where a higher number of molecular formulae were observed in headwater streams of undisturbed forested systems. ${ }^{20}$ Similarly, the functional diversity $\left(F_{\mathrm{D}}\right)$ reported for each FTICR-MS index was also not significantly different among small- and mediumorder streams (Figure $2 \mathrm{c}$ and Table S6), which suggests that anthropization of headwater systems may be a leading driver of changes in DOM molecular complexity such that traditional paradigms for predicting organic matter dynamics in natural systems become less pronounced when watershed disturbances are introduced.

In general, $F_{\mathrm{D}-\mathrm{N}}$ was highest in small and medium stream order samples compared to large stream orders, suggesting that there was a higher diversity of $\mathrm{N}$-containing compounds that are likely representative of bioavailable DOM in the upper watershed (ANOVA, Tukey's HSD, $p<0.05$ ). In contrast, the diversity in molecular weight $\left(F_{\mathrm{D}-m / z}\right)$ and highly aromatic compounds $\left(F_{\mathrm{D}-\mathrm{DBE}}\right)$ was significantly lower in the small and medium stream orders with respect to large stream orders
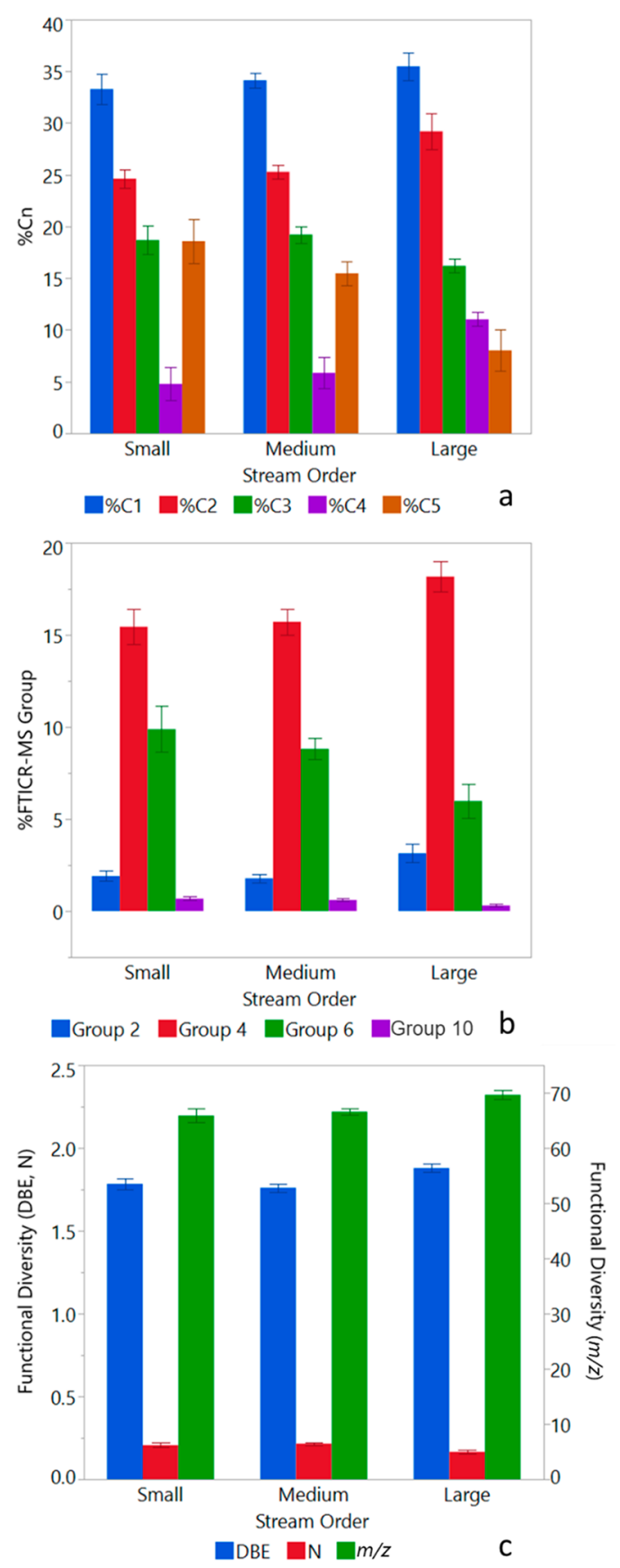

Figure 2. Distribution of (a) EEM-PARAFAC components and (b) FTICR-MS molecular compound classes, as well as (c) shifts in functional diversity measures as a function of stream order in the Altamaha River.

(ANOVA, Tukey's HSD, $p<0.05$; Figure 2c). As such, it seems likely that the changes in functional diversity along the Altamaha River continuum are reflective of systematic transformations in DOM dynamics as in situ processes and variable source inputs likely contribute to the composition of DOM exported throughout the watershed.

The DOM composition in the upper watershed primarily reflected an enhanced microbial (and/or autochthonous) signature. This is noted by higher relative proportions of both the microbial humic-like and protein-like fluorescence components C3 and C5 in the upper watershed, respectively (Figure 2a and Supporting Information for more information 
on PARAFAC components). There was no significant difference for either of these components among small and medium stream orders (ANOVA, Tukey's HSD, $p<0.05$; Figure 2a). Patterns displayed by the fluorescent DOM were further complemented on a molecular scale as compound classes generally considered to be microbially derived and/or bioavailable constituents (e.g., unsaturated aliphatic compounds with and without $\mathrm{N}$ ) were also more abundant in small- and medium-order streams (Figure $2 \mathrm{~b}$ ) compared to large stream orders. However, these compound classes were not significantly different between the small and medium stream orders (ANOVA, Tukey's HSD, $p>0.05$ ).

The original RCC hypothesized that organic matter would be clearly distinguishable between small- and medium-order streams as source inputs and biogeochemical processes alter the organic matter pool during downstream transport. ${ }^{19,21}$ For instance, small-order streams are expected to be highly heterotrophic, limited in light availability, and highly coupled to the terrestrial landscape. Thus, DOM would likely express a signature characteristic of allochthonous sources. Further downstream, an autotrophic environment is expected for medium stream orders as light availability increases (decreased tree canopy cover). Thus, the DOM would be expected to take on a less molecularly complex signature of autochthonous origin that also reflects the selective loss of labile compounds transported from smaller stream orders. Thus, for the Altamaha River, it could be expected that there would be a clear distinction among small- and medium-order streams for all indicators of molecular diversity, between "terrestrial-like" and "microbial-like" PARAFAC signatures and between FTICR-MS groups. However, the DOM composition in both small- and medium-order streams is clearly reflective of a microbial-like and/or bioreactive signature (Figure 2). ${ }^{35,58,59}$

The unconventional nature of the Altamaha River system, being that the greatest anthropogenic disturbances are within the upper headwaters (e.g., Atlanta Region, high agricultural activity; Figure S1 and Table S1), likely contributes to the inability to distinguish DOM composition between the smalland medium-order streams in the present study. As headwater streams are tightly coupled to the terrestrial environment, their structure and function are highly vulnerable and disproportionally affected by increasing anthropogenic activity compared to higher stream order rivers. ${ }^{60}$ For instance, the reduction of tree cover in anthropogenically disturbed systems ${ }^{61}$ and channelization of urbanized headwaters may induce loworder streams to behave more similarly to higher-order streams, ${ }^{38}$ enhancing the autotrophic contributions of DOM. In addition, agricultural practices will also significantly alter DOM composition in headwater streams. ${ }^{26,33,34,62,63}$ Thus, it is likely that DOM abundance, composition, and reactivity (in situ processing) are different in anthropogenically impacted headwaters compared to those in natural systems. As such, watershed land use may be the dominant driver and a better indicator of DOM composition in an anthropogenically disturbed system by comparison to the traditional RCC. On the other hand, in rivers where stream order and anthropogenic activities increase downstream, the shift to more autochthonous DOM signatures may even be more pronounced as observed in the Amazon River where nitrogen- and sulfur-containing moities increase with DOM inputs from populated regions close to the river mouth. ${ }^{64}$

The controls of land use on DOM composition have been linked to higher nutrient loads ${ }^{65-67}$ that fuel primary productivity $^{41}$ and production of more bioavailable DOM. ${ }^{26,35,58}$ In agreement, the Altamaha River TDN concentrations were highest in the upper watershed and was positively correlated to both urban $(r=0.54, p<0.01)$ and agricultural land use $(r=0.53, p<0.05)$, suggesting higher nutrient availability in this region. ${ }^{42,68}$ While TDN was linked to both urban and agricultural land use, the microbial-like (C3) and protein-like (C5) fluorescent DOM signatures were segregated among each land use type. For instance, a positive correlation was observed between PARAFAC component $\mathrm{C} 3$ and agriculture $(r=0.36, p<0.05)$ suggesting that DOM in agricultural streams is represented by a lower-molecularweight, microbially degraded humic-like signature. ${ }^{43}$ By comparison, the protein-like PARAFAC component C5 was positively correlated to urban land use $(r=0.50, p<0.05)$. Small urban streams are particularly vulnerable to increasing eutrophication and an autotrophic environment as leaky sewer and septic systems release nutrients that are transported from the groundwater to headwater streams. ${ }^{41,69,70}$ Thus, higher contributions of protein-like fluorescence and autochthonously derived, low-molecular-weight DOM are often observed in urban-influenced streams. ${ }^{35,58,71}$

While clear differences were observed within the fluorescent DOM pool as a function of anthropogenic land use, clear distinctions among FTICR-MS compound classes with anthropogenic land use were not observed as both the unsaturated aliphatic molecular formulae and unsaturated aliphatic compounds with nitrogen were each correlated with both agriculture and urbanization (Table 1). However, DOM derived from agricultural activity could clearly be distinguished from urban activity due to an enrichment in $\mathrm{N}$ functionality $(r=0.65, p<0.01)$ within the detected DOM molecular formulae, an observation consistent in riverine DOM on a global scale. ${ }^{72}$ Furthermore, we note an enrichment of sulfur moieties within the DOM pool as a function of urban land use $(r=0.47, p<0.01)$, which has been previously linked to wastewater treatment processes. ${ }^{73}$ Sulfur enrichment in DOM has also been linked to sulfate fertilizers as agricultural amendments, ${ }^{74,75}$ and in the Altamaha River, sulfur-containing moieties within the condensed aromatic fraction (e.g., dissolved black sulfur) have also been linked to agriculture. ${ }^{9}$ However, the relationship between sulfur in the bulk DOM was limited to urban areas within the Altamaha River watershed, highlighting the importance of wastewater treatment and other potential point urban sources from the Atlanta region on DOM composition in this system. Based on the strong relationship between DOM composition to anthropogenic land use coupled with a lack of major compositional differences between small and medium stream orders in the Altamaha River, it seems evident that anthropization of headwater systems inhibits the ability to predict DOM dynamics within the conceptual framework of the RCC. Instead, the linkages between DOM molecular composition with land use may be better indicators of stream ecosystem functions in anthropogenically impacted headwaters.

4.2. Controls of the RCC and Land Use on DOM Composition in the Lower Altamaha River. There was a clear difference in DOM functional diversity and composition in the large stream order samples compared to those in smalland medium-order streams in the upper watershed. This is most notable as the $F_{\mathrm{D}-\mathrm{N}}$ decreased in large stream orders (ANOVA, Tukey's HSD, $p<0.05$ ), suggesting either (1) the selective removal of dissolved organic nitrogen downstream; 
(2) the introduction of a nitrogen-depleted DOM source along the lower reaches of the Altamaha River watershed, or (3) a combination of both. Furthermore, the $F_{\mathrm{D}-m / z}$ and $F_{\mathrm{D}-\mathrm{DBE}}$ were each higher in large stream orders relative to small and medium stream orders (ANOVA, Tukey's HSD, $p<0.05$ ) suggesting the diversification of the DOM pool to include a greater distribution of compounds of varying size and aromaticity downstream relative to the upper headwaters. This observation is complemented as the relative contributions of the terrestrial humic-like PARAFAC components C2 and $\mathrm{C} 4$ were both more abundant in large stream orders compared to those in small- and medium-order streams (ANOVA, Tukey's HSD, $p<0.05$; Figure 2). For the FTICR-MS compound classes, the highly aromatic constituents (group 4) and polycondensed aromatic compounds (group 2) were also more abundant in large stream orders compared to those in small- and medium-order streams (ANOVA, Tukey's HSD, $p<$ 0.05 ; Figure 2). These results are generally consistent with predictions from the RCC such that a less bioreactive, more refractory carbon pool is transported downstream. ${ }^{19,21}$ On a global scale, Massicotte et al. ${ }^{22}$ also reported a profoundly less reactive DOM pool in the lower reaches of fluvial systems, an observation that was attributed to various degradation/removal processes as well as diminished coupling between aquatic systems and the surrounding terrestrial landscape. A series of biogeochemical processes may be responsible for the observed increase in aromatic DOM components downstream, including the removal of bioavailable DOM. An increase in aromatic, humic-like DOM may also indicate a reduction in photochemical degradation efficiency in the lower reaches of the Altamaha River when also considering a general increase in downstream turbidity in this system (large stream orders typically $>25$ NTU compared to small and medium stream orders that are typically $<25 \mathrm{NTU}$; Table S2). However, Altamaha River soils are rich with iron and contribute significantly to the riverine suspended particulates. ${ }^{77,78}$ Thus, it may be expected that DOM sorption to suspended particulates would be enhanced in this system as turbidity increases downstream. ${ }^{14,17,79}$ However, the observed continuous increase in the aromatic, humic-like DOM character downstream may indicate that DOM-mineral sorption mechanisms are (1) minimal in this system or (2) quantitatively less important with respect to other landcover-driven sources of terrestrial-like DOM downstream.

While the enhanced aromatic DOM signatures and depletion of $\mathrm{N}$-containing DOM with increasing stream order would be generally expected based on the RCC, longitudinal shifts in DOM composition have also been strongly linked to watershed land cover, ${ }^{80}$ and more specifically to watershed connectivity with wetlands. ${ }^{81,82}$ In this system, wetlands accounted for $10-15 \%$ of the land cover in the lower watershed compared to less than $6 \%$ in the upper watershed (Table S1 and Figure 1). Wetlands are generally considered good predictors of both DOC concentration ${ }^{83,84}$ and DOM composition. $^{37,85}$ In the Altamaha River, wetlands were also good predictors of DOM composition as there was a significant relationship with all five PARAFAC components, as well as 9 of the 10 molecular compound classes established by FTICRMS (Table 1). In this study, wetlands were positively correlated with the humic-like PARAFAC components $\mathrm{C} 1(r$ $=0.56, p<0.01), \mathrm{C} 2(r=0.78, p<0.01)$, and C4 $(r=0.74, p$ $<0.01)$. In addition, wetlands were also positively correlated with FTICR-MS compound classes representing condensed
Table 1. Pearson's Product-Moment Correlation Coefficient $(r)$ Showing Correlations between Watershed Land Use with Water Quality Parameters, EEM-PARAFAC Components, and FTICR-MS Molecular Compound Classes that Are Significant with $p<0.01$ and $p<0.05^{a}$

\begin{tabular}{|c|c|c|c|c|}
\hline & urban & forest & agriculture & wetland \\
\hline DOC & & & & 0.79 \\
\hline TDN & 0.54 & -0.52 & 0.43 & -0.50 \\
\hline turbidity & & & & 0.88 \\
\hline $\mathrm{C} 1$ & -0.48 & & & 0.56 \\
\hline $\mathrm{C} 2$ & -0.47 & 0.37 & & 0.78 \\
\hline $\mathrm{C} 3$ & & & 0.36 & -0.45 \\
\hline $\mathrm{C} 4$ & & & & 0.61 \\
\hline $\mathrm{C} 5$ & 0.50 & & & -0.88 \\
\hline group 1 & -0.46 & 0.37 & & 0.72 \\
\hline group 2 & -0.40 & & & 0.74 \\
\hline group 3 & -0.32 & & 0.40 & 0.49 \\
\hline group 4 & -0.49 & & & 0.78 \\
\hline group 5 & & & & -0.36 \\
\hline group 6 & 0.36 & & 0.31 & -0.70 \\
\hline group 7 & & & & -0.62 \\
\hline group 8 & & & & \\
\hline group 9 & 0.38 & & & -0.40 \\
\hline group 10 & 0.37 & -0.33 & 0.37 & -0.71 \\
\hline
\end{tabular}

${ }^{a}$ FTICR-MS groups include (1) $\mathrm{AI}_{\text {mod }}>0.67,15$ carbon atoms, (2) condensed aromatic compounds $\geq 15$ carbon atoms, (3) condensed aromatic compounds with heteroatoms, (4) highly aromatic compounds including polyphenols, (5) highly unsaturated compounds, (6) unsaturated aliphatics, (7) saturated compounds with low $\mathrm{O} / \mathrm{C}$ ratios and with heteroatoms, (8) saturated compounds with high $\mathrm{O} / \mathrm{C}$ ratios including carbohydrates, (9) saturated compounds with high $\mathrm{O} / \mathrm{C}$ and with heteroatoms, and (10) unsaturated aliphatic molecular formulae with nitrogen.

aromatic compounds $(r=0.74, p<0.01)$ and highly aromatic compounds $(r=0.78, p<0.01)$. These observations are consistent with previous reports that an enrichment of aromatic DOM in fluvial systems can be linked to the proportion of wetlands within the watershed. ${ }^{37,86}$ In a similar manner to the data reported in the upper Altamaha River watershed in the present study, these very strong relationships presented between wetland cover and DOM composition (both PARAFAC and FTICR-MS compound classes) may further indicate that land use is a stronger indicator of molecular DOM dynamics in the Altamaha River compared to the RCC. Thus, the ability to tease apart relative controls of both land use and the RCC on explaining DOM dynamics would be an important means for predicting future changes in fluvial networks and the implications for coastal systems as anthropogenic activities continue to increase globally.

4.3. Spatial Variability in DOM Composition: Land Use vs. Stream Order (RCC). The data presented in the previous sections show clear trends in DOM composition throughout the Altamaha River watershed relating to watershed land use and, in part, stream order (e.g., RCC). To semiquantitatively better assess the individual contributions of both the RCC and land use in explaining DOM compositional variability within the watershed, we applied redundancy analysis (RDA). RDA is considered a technique for cross validation of linear relationships between predictor and response variables, and the established relationships between land use and stream order with DOM composition are displayed within an RDA (Figure 3). As a whole, the RDA 

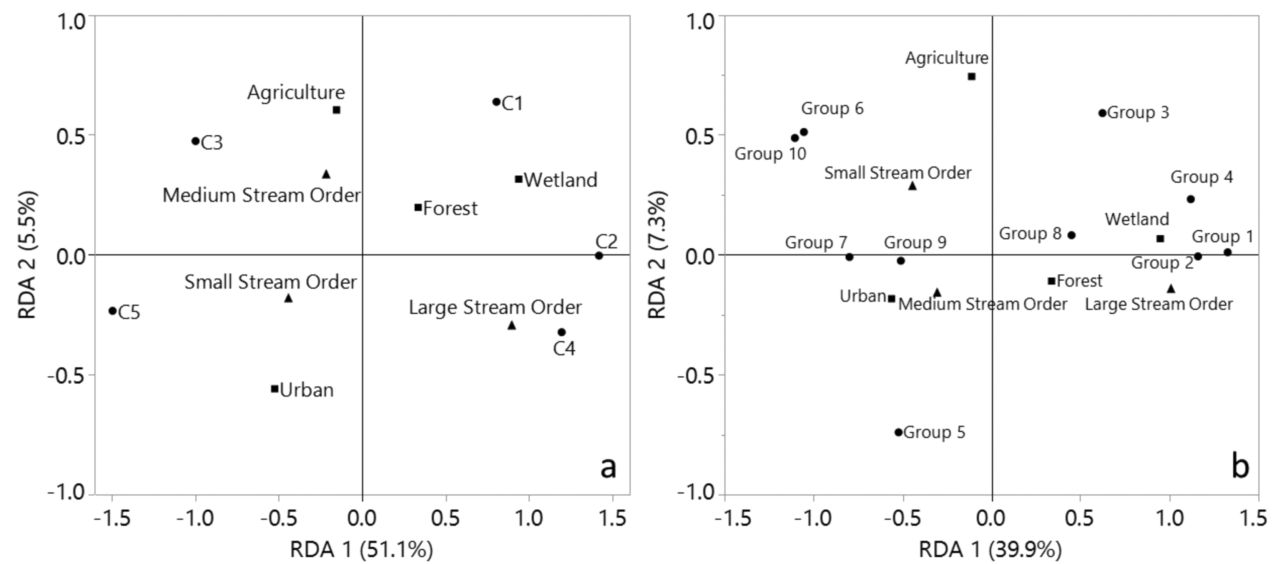

Figure 3. Redundancy analysis using stream order (i.e., RCC) and land use as predictor variables for the spatial distribution of (a) EEMPARAFAC components and (b) FTICR-MS molecular compound classes in the Altamaha River watershed. FTICR-MS groups include (1) AI mod $>$ $0.67,<15$ carbon atoms, (2) condensed aromatic compounds $\geq 15$ carbon atoms, (3) condensed aromatic compounds with heteroatoms, (4) highly aromatic compounds including polyphenols, (5) highly unsaturated compounds, (6) unsaturated aliphatics, (7) saturated compounds with low $\mathrm{O} /$ $\mathrm{C}$ ratios and with heteroatoms, (8) saturated compounds with high $\mathrm{O} / \mathrm{C}$ ratios including carbohydrates, (9) saturated compounds with high $\mathrm{O} / \mathrm{C}$ and with heteroatoms, and (10) unsaturated aliphatic molecular formulae with nitrogen.

model suggests that $59 \%$ of the total spatial variability of DOM composition represented by EEM-PARAFAC (Figure 3a) can be explained as a combined function of stream order and land use. Of this 59\% explained variability, land use contributed $52 \%$ compared to $7 \%$ by stream order (Table S8). By comparison, the RDA model explained $53 \%$ of the spatial variability in DOM composition represented as DOM molecular compound classes from FTICR-MS analysis (Figure $3 \mathrm{~b})$. Land use was again estimated at a higher contribution (45\%) compared to stream order ( $8 \%$, Table S8).

For both EEM-PARAFAC and FTICR-MS models, RDA 1 represented the only statistically significant axis and contributed 51.1\% $(p<0.001$; Table S8) and 39.9\% $(p<0.001$; Table S8) to each model, respectively. In both cases, RDA 1 represents a clear distinction between DOM composition among the anthropogenically disturbed upper watershed (small and medium stream orders) and the higher-order streams and wetlands in the lower watershed. The relationships between anthropogenic land use with microbial humic-like and protein-like fluorescence components (C3 and C5), as well as molecular compound classes such as unsaturated aliphatic- and unsaturated nitrogen-containing molecular formulae, were each observed at negative RDA 1 (Figure 3). This is in contrast to the relatively natural and undisturbed lower Altamaha River watershed (larger stream order) observed at positive RDA 1 that was associated with terrestrial humic-like components (C1, C2, and C4; Figure 3a) and more aromatic molecular formulae, such as polycondensed aromatic compounds and highly aromatic compounds (Figure $3 \mathrm{~b}$ ).

For the EEM-PARAFAC dataset, linear regression analysis provided a clear distinction between the microbial humic-like (C3) and protein-like (C5) components as a function of agriculture and urban land use, respectively (Table 1). This distinction is further observed along RDA 2 in Figure 3a, and the separation of agricultural land cover and urbanization and their controls on FTICR-MS molecular compound groups is further observed along RDA 2 in Figure 3b. However, RDA 2 was not statistically significant in either of the PARAFAC or FTICR-MS RDA models ( $p>0.05$, for both models). This suggests that the distinction between urban and agricultural land use along RDA 2 as explanatory factors of DOM composition is minimal with respect to the amount of variability that can be explained within each model. Rather, the explained variability in DOM as defined by both EEMPARAFAC and FTICR-MS is best represented by a distinction between total anthropogenic land cover (urban and agricultural) observed negatively along RDA 1 with natural wetland cover as observed positively along RDA $1(p<0.001$ in each case). As the spatial variability of DOM was best explained with RDA models by land use (Table S8), it becomes evident that land use is a dominant driver of DOM composition in anthropogenically impacted systems with respect to varying biogeochemical controls that would be expected based on the RCC.

There is still, however, about $45 \%$ of the variability in the data that remain unexplained within this system, which is likely related to other anthropogenic and/or environmental drivers of DOM composition in fluvial networks. For instance, water residence time, precipitation, discharge (groundwater versus high flow), soil type, and temperature have all also been linked to DOM composition in a variety of systems. ${ }^{23,26,87-91}$ Increasing water residence time through river damming or increasing lake area, for example, may alter DOM transport through increasing sedimentation, in situ DOM production, and respiration, ${ }^{29,92}$ further complicating predictions by the RCC. Atmospheric deposition patterns can also alter soil organic matter dynamics and has been linked to increased browning of surface waters as a result of reduced sulfate deposition. ${ }^{93}$ Despite the present study representing a "snapshot" in time, we also recognize that seasonal hydrology has also been linked to DOM dynamics in fluvial systems. In a similar study at a smaller scale, Kothawala et al. ${ }^{27}$ have suggested that land cover in boreal streams could explain 49\% of the observed DOM composition, while an additional $8 \%$ could be explained by seasonality. However, at the watershed scale, Raymond et al. ${ }^{30}$ suggest that seasonal hydrologic events become an integral driver of DOM in which the rapid transport of terrestrial DOM downstream leads to little processing due to decreasing water residence times. In the Altamaha River, DOM export to the coastal zone has been linked to watershed hydrology in concert to land use. ${ }^{94,95}$ While seasonal hydrology was not considered in this study, we suspect that 
anthropization will begin to have long-term impacts on DOM quality transported in fluvial systems across hydrological scales, further complicating predictions using the RCC. Nonetheless, while a significant fraction of DOM variability can be explained in this study, we suspect that a portion of the remaining $45 \%$ of unexplained variation in DOM composition within the Altamaha River watershed could be explained with soil dynamics and/or as a function of river hydrology.

\section{CONCLUSIONS}

Since the early 1980s, the RCC has provided a synthetic framework for predicting ecological functions of fluvial systems from the source to river mouth. Here, we semiquantitatively assessed if the RCC is applicable to predict fluvial DOM transport in watersheds with strong anthropogenic disturbances. Land use was the strongest predictor of DOM dynamics throughout the watershed. An autochthonous and/or microbial DOM signature was generally characterisitic of the anthropogenically impacted upper headwaters where an enrichment of aliphatic- and heteroatom-containing DOM compounds was observed. Relatively more aromatic compounds were found in the more pristine lower watershed reflecting mobilized terrestrial DOM inputs. The low explanatory power of the RCC with respect to land use for DOM predictions further emphasizes its limitations as a predictive tool for watersheds with anthropogenically impacted headwaters. While the general biogeochemical transformations of DOM along an undisturbed river continuum (no significant changes in land use) have been predicted reasonably well based on the RCC, ${ }^{20,24}$ the Altamaha River watershed is unique in that its headwaters are among the most anthropogenically disturbed, and such disturbances are becoming more commonplace in river systems worldwide. ${ }^{36}$ In addition, the drainage of river systems into the ocean through highly populated coastal regions will further affect the quality of DOM reaching coastal systems. ${ }^{36,64}$ However, while future studies are still needed to address these concerns, the current study highlights the need to integrate land use with future adaptations of the RCC, including studies aiming to investigate the RCC-land use coupling over both spatial and temporal scales. While some spatial and hydrological limitations to the RCC have been previously addressed, ${ }^{28-30}$ the continued refinement of models such as the RCC will only improve our understanding of DOM biogeochemical cycling and the response of fluvial networks to future urban and agricultural development and climate change.

\section{ASSOCIATED CONTENT}

\section{S Supporting Information}

The Supporting Information is available free of charge at https://pubs.acs.org/doi/10.1021/acs.est.9b04605.

Sample locations within the upper watershed (Oconee River tributary) and lower watershed (lower Oconee River and Altamaha River) (Figure S1); five-component PARAFAC model for the Altamaha River (Figure S2); list of sample locations (Table S1); average land use type for small, medium, and large stream orders (Table S2); measurements of water quality parameters, optical properties, and relative contributions of PARAFAC components (Table S3); characterization of EEMPARAFAC components (Table S4); FTICR-MS weighted molecular parameters for each sampling location (Table S5); total number of molecular formulae detected and the calculated functional diversity for molecular weight $\left(F_{\mathrm{D}-m / z}\right)$, double-bond equivalents $\left(F_{\mathrm{D}-\mathrm{DBE}}\right)$, and nitrogen-containing compounds $\left(F_{\mathrm{D}-\mathrm{N}}\right)$ (Table S6); relative intensity weighted contributions of each FTICR-MS molecular compound class (Table S7); and statistical information for RDA models (Table S8) (PDF)

\section{AUTHOR INFORMATION}

\section{Corresponding Author}

*E-mail: jaroebuck@mun.ca. Phone: 709.864.3001.

ORCID

Jesse Alan Roebuck, Jr.: 0000-0002-8575-2572

Michael Seidel: 0000-0003-0934-1939

Rudolf Jaffé: 0000-0001-6153-248X

\section{Present Address}

${ }^{\S}$ Department of Earth Sciences, Memorial University of Newfoundland, St. John's, NL A1C 5S7, Canada (J.A.R.).

\section{Notes}

The authors declare no competing financial interest.

\section{ACKNOWLEDGMENTS}

The authors greatly appreciate assistance from Nicolas Jaffe with GIS processing of land use data. The authors thank Drs. Patricia Medeiros and Aron Stubbins for providing logistical support at the University of Georgia for sample processing during their fieldwork. The authors also extend their thanks to both David Podgorski and Phoebe Zito (University of New Orleans) as well as Kaelin Cawley (National Ecological Observatory Network) for assistance in the development of the PARAFAC model. This research was funded through the George Barley Endowment (to R.J.). This is contribution number 934 from the Southeast Environmental Research Center at the Institute of Water and Environment at FIU.

\section{REFERENCES}

(1) Cai, W.-J. Estuarine and Coastal Ocean Carbon Paradox: $\mathrm{CO}_{2}$ Sinks or Sites of Terrestrial Carbon Incineration? Annu. Rev. Mar. Sci. 2011, 3, 123-145.

(2) Markager, S.; Stedmon, C.; Conan, P. Effects of DOM in Marine Ecosystems. In Dissolved Organic Matter (DOM) in Aquatic Ecosystems: A study of European Catchments and Coastal Waters; Søndergaard, M., Thomas, D. N., Eds.; Domaine Project: 2004; pp $37-42$.

(3) Häder, D.-P.; Helbling, E. W.; Williamson, C. E.; Worrest, R. C. Effects of UV radiation on aquatic ecosystems and interactions with climate change. Photoch. Photobiol. Sci. 2011, 10, 242-260.

(4) del Giorgio, P. A.; Williams, P. The Global Significance of Respiration in Aquatic Ecosystems: From Sing Cells to the Biosphere. In Respiration in Aquatic Ecosystems; Del Giorgio, P. A., Williams, P., Eds.; Oxford University Press: Oxford, 2005; pp 267-303.

(5) Battin, T. J.; Kaplan, L. A.; Findlay, S.; Hopkinson, C. S.; Marti, E.; Packman, A. I.; Newbold, J. D.; Sabater, F. Biophysical controls on organic carbon fluxes in fluvial networks. Nat. Geosci. 2008, 1, 95100.

(6) Aiken, G. R.; Gilmour, C. C.; Krabbenhoft, D. P.; Orem, W. Dissolved Organic Matter in the Florida Everglades: Implications for Ecosystem Restoration. Crit. Rev. Environ. Sci. Technol. 2011, 41, 217-248.

(7) Raymond, P. A.; Hartmann, J.; Lauerwald, R.; Sobek, S.; McDonald, C.; Hoover, M.; Butman, D.; Striegl, R. G.; Mayorga, E.; Humborg, C.; Pirkko, K.; Dürr, H.; Meybeck, M.; Ciais, P.; Guth, P. Global carbon dioxide emissions from inland waters. Nature 2013, 503, 355-359. 
(8) Cole, J. J.; Prairie, Y. T.; Caraco, N. F.; McDowell, W. H.; Tranvik, L. J.; Striegl, R. G.; Duarte, C. M.; Kortelainen, P.; Downing, J. A.; Middelburg, J. J.; Melack, J. Plumbing the Global Carbon Cycle: Integrating Inland Waters into the Terrestrial Carbon Budget. Ecosystems 2007, 10, 172-185.

(9) Bianchi, T. S.; Filley, T.; Dria, K.; Hatcher, P. G. Temporal variability in sources of dissolved organic carbon in the lower Mississippi river. Geochim. Cosmochim. Acta 2004, 68, 959-967.

(10) Hedges, J. I.; Cowie, G. L.; Richey, J. E.; Quay, P. D.; Benner, R.; Strom, M.; Forsberg, B. R. Origins and processing of organic matter in the Amazon River as indicated by carbohydrates and amino acids. Limnol. Oceanogr. 1994, 39, 743-761.

(11) Massicotte, P.; Frenette, J.-J. Spatial connectivity in a large river system: resolving the sources and fate of dissolved organic matter. Ecol. Appl. 2011, 21, 2600-2617.

(12) Kothawala, D. N.; Stedmon, C. A.; Müller, R. A.; Weyhenmeyer, G. A.; Köhler, S. J.; Tranvik, L. J. Controls of dissolved organic matter quality: evidence from a large-scale boreal lake survey. Global Change Biol. 2014, 20, 1101-1114.

(13) Amon, R. M. W.; Benner, R. Photochemical and microbial consumption of dissolved organic carbon and dissolved oxygen in the Amazon River system. Geochim. Cosmochim. Acta 1996, 60, 17831792.

(14) Philippe, A.; Schaumann, G. E. Interactions of Dissolved Organic Matter with Natural and Engineered Inorganic Colloids: A Review. Environ. Sci. Technol. 2014, 48, 8946-8962.

(15) Yamashita, Y.; Jaffé, R. Characterizing the Interactions between Trace Metals and Dissolved Organic Matter Using ExcitationEmission Matrix and Parallel Factor Analysis. Environ. Sci. Technol. 2008, 42, 7374-7379.

(16) von Wachenfeldt, E.; Tranvik, L. J. Sedimentation in Boreal Lakes-The Role of Flocculation of Allochthonous Dissolved Organic Matter in the Water Column. Ecosystems 2008, 11, 803-814.

(17) Du, Y.; Ramirez, C. E.; Jaffe, R. Fractionation of Dissolved Organic Matter by Co-Precipitation with Iron: Effects of Composition. Environ. Process. 2018, 5, 5-21.

(18) Amon, R. M. W.; Benner, R. Bacterial utilization of different size classes of dissolved organic matter. Limnol. Oceanogr. 1996, 41, $41-51$.

(19) Vannote, R. L.; Minshall, G. W.; Cummins, K. W.; Sedell, J. R.; Cushing, C. E. The River Continuum Concept. Can. J. Fish Aquat. Sci. 1980, 37, 130-137.

(20) Mosher, J.; Kaplan, L.; Podgorski, D.; McKenna, A.; Marshall, A. Longitudinal shifts in dissolved organic matter chemogeography and chemodiversity within headwater streams: a river continuum reprise. Biogeochemistry 2015, 124, 371-385.

(21) Creed, I. F.; McKnight, D. M.; Pellerin, B. A.; Green, M. B.; Bergamaschi, B. A.; Aiken, G. R.; Burns, D. A.; Findlay, S. E. G.; Shanley, J. B.; Striegl, R. G.; Aulenbach, B. T.; Clow, D. W.; Laudon, H.; McGlynn, B. L.; McGuire, K. J.; Smith, R. A.; Stackpoole, S. M. The river as a chemostat: fresh perspectives on dissolved organic matter flowing down the river continuum. Can. J. Fish Aquat. Sci. 2015, 72, 1272-1285.

(22) Massicotte, P.; Asmala, E.; Stedmon, C.; Markager, S. Global distribution of dissolved organic matter along the aquatic continuum: Across rivers, lakes and oceans. Sci. Total Environ. 2017, 609, 180191.

(23) Weyhenmeyer, G. A.; Fröberg, M.; Karltun, E.; Khalili, M.; Kothawala, D.; Temnerud, J.; Tranvik, L. J. Selective decay of terrestrial organic carbon during transport from land to sea. Global Change Biol. 2012, 18, 349-355.

(24) Coble, A. A.; Koenig, L. E.; Potter, J. D.; Parham, L. M.; McDowell, W. H. Homogenization of dissolved organic matter within a river network occurs in the smallest headwaters. Biogeochemistry 2019, 143, 85-104.

(25) Hutchins, R. H. S.; Aukes, P.; Schiff, S. L.; Dittmar, T.; Prairie, Y. T.; del Giorgio, P. A. The Optical, Chemical, and Molecular Dissolved Organic Matter Succession Along a Boreal Soil-StreamRiver Continuum. J. Geophys. Res.: Biogeosci. 2017, 122, 2892-2908.
(26) Shang, P.; Lu, Y.; Du, Y.; Jaffé, R.; Findlay, R. H.; Wynn, A. Climatic and watershed controls of dissolved organic matter variation in streams across a gradient of agricultural land use. Sci. Total Environ. 2018, 612, 1442-1453.

(27) Kothawala, D. N.; Ji, X.; Laudon, H.; Ågren, A. M.; Futter, M. N.; Köhler, S. J.; Tranvik, L. J. The relative influence of land cover, hydrology, and in-stream processing on the composition of dissolved organic matter in boreal streams. J. Geophys. Res.: Biogeosci. 2015, 120, $1491-1505$.

(28) Ward, J. V.; Stanford, J. A. The Serial Discontinuity Concept of Lotic Ecosystems. In Dynamics of Lotic Ecosystems; Fontain, T. D., Bartell, S. M., Eds.; Ann Arbor Science: Ann Arbor, 1983; pp 29-42.

(29) Junk, J. W.; Bayley, P. B.; Sparks, R. E. The flood pulse concept in river flood plain systems. Can. J. Fish Aquat. Sci. 1989, 106, 110127.

(30) Raymond, P. A.; Saiers, J. E.; Sobczak, W. V. Hydrological and biogeochemical controls on watershed dissolved organic matter transport: pulse-shunt concept. Ecology 2016, 97, 5-16.

(31) Yamashita, Y.; Kloeppel, B. D.; Knoepp, J.; Zausen, G. L.; Jaffé, R. Effects of Watershed History on Dissolved Organic Matter Characteristics in Headwater Streams. Ecosystems 2011, 14, 11101122.

(32) Cawley, K. M.; Campbell, J.; Zwilling, M.; Jaffé, R. Evaluation of forest disturbance legacy effects on dissolved organic matter characteristics in streams at the Hubbard Brook Experimental Forest, New Hampshire. Aquat. Sci. 2014, 76, 611-622.

(33) Williams, C. J.; Yamashita, Y.; Wilson, H. F.; Jaffe, R.; Xenopoulos, M. A. Unraveling the role of land use and microbial activity in shaping dissolved organic matter characteristics in stream ecosystems. Limnol. Oceanogr. 2010, 55, 1159-1171.

(34) Wilson, H. F.; Xenopoulos, M. A. Effects of agricultural land use on the composition of fluvial dissolved organic matter. Nat. Geosci. 2009, 2, 37-41.

(35) Parr, T. B.; Cronan, C. S.; Ohno, T.; Findlay, S. E. G.; Smith, S. M. C.; Simon, K. S. Urbanization changes the composition and bioavailability of dissolved organic matter in headwater streams. Limnol. Oceanogr. 2015, 60, 885-900.

(36) Foley, J. A.; DeFries, R.; Asner, G. P.; Barford, C.; Bonan, G.; Carpenter, S. R.; Chapin, F. S.; Coe, M. T.; Daily, G. C.; Gibbs, H. K.; Helkowski, J. H.; Holloway, T.; Howard, E. A.; Kucharik, C. J.; Monfreda, C.; Patz, J. A.; Prentice, I. C.; Ramankutty, N.; Snyder, P. K. Global Consequences of Land Use. Science 2005, 309, 570-574.

(37) Lambert, T.; Teodoru, C. R.; Nyoni, F. C.; Bouillon, S.; Darchambeau, F.; Massicotte, P.; Borges, A. V. Along-stream transport and transformation of dissolved organic matter in a large tropical river. Biogeosciences 2016, 13, 2727-2741.

(38) Elmore, A. J.; Kaushal, S. S. Disappearing headwaters: patterns of stream burial due to urbanization. Front. Ecol. Environ. 2008, 6, $308-312$.

(39) Groffman, P. M.; Boulware, N. J.; Zipperer, W. C.; Pouyat, R. V.; Band, L. E.; Colosimo, M. F. Soil Nitrogen Cycle Processes in Urban Riparian Zones. Environ. Sci. Technol. 2002, 36, 4547-4552.

(40) Paul, M. J.; Meyer, J. L. Streams in the Urban Landscape. Annu. Rev. Ecol. Syst. 2001, 32, 333-365.

(41) Finlay, J. C. Stream size and human influences on ecosystem production in river networks. Ecosphere 2011, 2, No. art87.

(42) Schaefer, S. C.; Alber, M. Temporal and spatial trends in nitrogen and phosphorus inputs to the watershed of the Altamaha River, Georgia, USA. Biogeochemistry 2007, 86, 231-249.

(43) Strahler, A. N. Quantitative analysis of watershed geomorphology. Trans., Am. Geophys. Union 1957, 38, 913-920.

(44) Dittmar, T.; Koch, B.; Hertkorn, N.; Kattner, G. A simple and efficient method for the solid-phase extraction of dissolved organic matter (SPE-DOM) from seawater. Limnol. Oceanogr.: Methods 2008, $6,230-235$.

(45) Ohno, T. Fluorescence Inner-Filtering Correction for Determining the Humification Index of Dissolved Organic Matter. Environ. Sci. Technol. 2002, 36, 742-746. 
(46) Murphy, K. R.; Stedmon, C. A.; Graeber, D.; Bro, R. Fluorescence spectroscopy and multi-way techniques. PARAFAC. Anal. Methods 2013, 5, 6557-6566.

(47) Seidel, M.; Beck, M.; Riedel, T.; Waska, H.; Suryaputra, I. G. N. A.; Schnetger, B.; Niggemann, J.; Simon, M.; Dittmar, T. Biogeochemistry of dissolved organic matter in an anoxic intertidal creek bank. Geochim. Cosmochim. Acta 2014, 140, 418-434.

(48) Riedel, T.; Dittmar, T. A Method Detection Limit for the Analysis of Natural Organic Matter via Fourier Transform Ion Cyclotron Resonance Mass Spectrometry. Anal. Chem. 2014, 86, $8376-8382$.

(49) Koch, B. P.; Dittmar, T. From mass to structure: an aromaticity index for high-resolution mass data of natural organic matter. Rapid Commun. Mass Spectrom. 2016, 30, 250.

(50) Koch, B. P.; Dittmar, T. From mass to structure: an aromaticity index for high-resolution mass data of natural organic matter. Rapid Commun. Mass Spectrom. 2006, 20, 926-932.

(51) Botta-Dukát, Z. Rao's quadratic entropy as a measure of functional diversity based on multiple traits. J. Veg. Sci. 2005, 16, 533-540.

(52) Mentges, A.; Feenders, C.; Seibt, M.; Blasius, B.; Dittmar, T. Functional Molecular Diversity of Marine Dissolved Organic Matter Is Reduced during Degradation. Front. Mar. Sci. 2017, 4, No. 194.

(53) Landa, M.; Cottrell, M. T.; Kirchman, D. L.; Kaiser, K.; Medeiros, P. M.; Tremblay, L.; Batailler, N.; Caparros, J.; Catala, P.; Escoubeyrou, K.; Oriol, L.; Blain, S.; Obernosterer, I. Phylogenetic and structural response of heterotrophic bacteria to dissolved organic matter of different chemical composition in a continuous culture study. Environ. Microbiol. 2014, 16, 1668-1681.

(54) Stubbins, A.; Spencer, R. G. M.; Chen, H.; Hatcher, P. G.; Mopper, K.; Hernes, P. J.; Mwamba, V. L.; Mangangu, A. M.; Wabakanghanzi, J. N.; Six, J. Illuminated darkness: Molecular signatures of Congo River dissolved organic matter and its photochemical alteration as revealed by ultrahigh precision mass spectrometry. Limnol. Oceanogr. 2010, 55, 1467-1477.

(55) Wiegner, T. N.; Seitzinger, S. P.; Glibert, P. M.; Bronk, D. A. Bioavailability of dissolved organic nitrogen and carbon from nine rivers in the eastern United States. Aquat. Microb. Ecol. 2006, 43, $277-287$.

(56) Oksanen, J.; Blanchet, F. G.; Kindt, R.; Legendre, P.; Micnchin, P. R.; O’Hara, R. B.; Simpson, G. L.; Solymos, P.; Stevens, M. H. H.; Wagner, H. Vegan: Community Ecology Package. R Package, version 2.3-0, 2015. http://CRAN.R-project.org/package=vegan.

(57) R Core Team. R: A Language and Environment for Statistical Computing; R Foundation for Statistical Computing: Vienna, 2015. http://www.R-project.org/.

(58) Hosen, J. D.; McDonough, O. T.; Febria, C. M.; Palmer, M. A. Dissolved Organic Matter Quality and Bioavailability Changes Across an Urbanization Gradient in Headwater Streams. Environ. Sci. Technol. 2014, 48, 7817-7824.

(59) Kim, S.; Kaplan, L. A.; Hatcher, P. G. Biodegradable dissolved organic matter in a temperate and a tropical stream determined from ultra-high resolution mass spectrometry. Limnol. Oceanogr. 2006, 51, $1054-1063$.

(60) Hynes, H. The stream and its valley. Int. Ver. Theor. Angew. Limnol. 1975, 19, 1-15.

(61) Nowak, D. J.; Greenfield, E. J. Tree and impervious cover change in U.S. cities. Urban For. Urban Greening 2012, 11, 21-30.

(62) Lu, Y.; Bauer, J. E.; Canuel, E. A.; Yamashita, Y.; Chambers, R. M.; Jaffé, R. Photochemical and microbial alteration of dissolved organic matter in temperate headwater streams associated with different land use. J. Geophys. Res.: Biogeosci. 2013, 118, 566-580.

(63) Lu, Y. H.; Bauer, J. E.; Canuel, E. A.; Chambers, R. M.; Yamashita, Y.; Jaffe, R.; Barrett, A. Effects of land use on sources and ages of inorganic and organic carbon in temperate headwater streams. Biogeochemistry 2014, 119, 275-292.

(64) Seidel, M.; Dittmar, T.; Ward, N. D.; Krusche, A. V.; Richey, J. E.; Yager, P. L.; Medeiros, P. M. Seasonal and spatial variability of dissolved organic matter composition in the lower Amazon River. Biogeochemistry 2016, 131, 281-302.

(65) Carpenter, S. R.; Caraco, N. F.; Correll, D. L.; Howarth, R. W.; Sharpley, A. N.; Smith, V. H. Nonpoint Pollution of Surface Waters with Phosphorus and Nitrogen. Ecol. Appl. 1998, 8, 559-568.

(66) Fuß, T.; Behounek, B.; Ulseth, A. J.; Singer, G. A. Land use controls stream ecosystem metabolism by shifting dissolved organic matter and nutrient regimes. Freshwater Biol. 2017, 62, 582-599.

(67) Kaushal, S. S.; Belt, K. T. The urban watershed continuum: evolving spatial and temporal dimensions. Urban Ecosyst. 2012, 15, 409-435.

(68) Weston, N. B.; Hollibaugh, J. T.; Joye, S. B. Population growth away from the coastal zone: Thirty years of land use change and nutrient export in the Altamaha River, GA. Sci. Total Environ. 2009, 407, 3347-3356.

(69) Kaushal, S. S.; Groffman, P. M.; Band, L. E.; Elliott, E. M.; Shields, C. A.; Kendall, C. Tracking Nonpoint Source Nitrogen Pollution in Human-Impacted Watersheds. Environ. Sci. Technol. 2011, 45, 8225-8232.

(70) Kaushal, S. S.; Lewis, W. M., Jr.; McCutchan, J. H., Jr. Land Use Change And Nitrogen Enrichment Of A Rocky Mountain Watershed. Ecol. Appl. 2006, 16, 299-312.

(71) McElmurry, S. P.; Long, D. T.; Voice, T. C. Stormwater Dissolved Organic Matter: Influence of Land Cover and Environmental Factors. Environ. Sci. Technol. 2014, 48, 45-53.

(72) Wagner, S.; Riedel, T.; Niggemann, J.; Vähätalo, A. V.; Dittmar, T.; Jaffé, R. Linking the Molecular Signature of Heteroatomic Dissolved Organic Matter to Watershed Characteristics in World Rivers. Environ. Sci. Technol. 2015, 49, 13798-13806.

(73) Gonsior, M.; Zwartjes, M.; Cooper, W. J.; Song, W.; Ishida, K. P.; Tseng, L. Y.; Jeung, M. K.; Rosso, D.; Hertkorn, N.; SchmittKopplin, P. Molecular characterization of effluent organic matter identified by ultrahigh resolution mass spectrometry. Water Res. 2011, 45, 2943-2953.

(74) Poulin, B. A.; Ryan, J. N.; Nagy, K. L.; Stubbins, A.; Dittmar, T.; Orem, W.; Krabbenhoft, D. P.; Aiken, G. R. Spatial Dependence of Reduced Sulfur in Everglades Dissolved Organic Matter Controlled by Sulfate Enrichment. Environ. Sci. Technol. 2017, 51, 3630-3639.

(75) Hertkorn, N.; Harir, M.; Cawley, K. M.; Schmitt-Kopplin, P.; Jaffé, R. Molecular characterization of dissolved organic matter from subtropical wetlands: a comparative study through the analysis of optical properties, NMR and FTICR/MS. Biogeosciences 2016, 13, 2257-2277.

(76) Roebuck, J. A.; Seidel, M.; Dittmar, T.; Jaffé, R. Land Use Controls on the Spatial Variability of Dissolved Black Carbon in a Subtropical Watershed. Environ. Sci. Technol. 2018, 52, 8104-8114.

(77) Bhatti, A. M.; Rundquist, D.; Schalles, J.; Ramirez, L.; Nasu, S. A comparison between above-water surface and subsurface spectral reflectances collected over inland waters. Geocarto Int. 2009, 24, 133141.

(78) Shi, W.; Sun, M.-Y.; Molina, M.; Hodson, R. E. Variability in the distribution of lipid biomarkers and their molecular isotopic composition in Altamaha estuarine sediments: implications for the relative contribution of organic matter from various sources. Org. Geochem. 2001, 32, 453-467.

(79) Kothawala, D. N.; Roehm, C.; Blodau, C.; Moore, T. R. Selective adsorption of dissolved organic matter to mineral soils. Geoderma 2012, 189-190, 334-342.

(80) Ward, N. D.; Krusche, A. V.; Sawakuchi, H. O.; Brito, D. C.; Cunha, A. C.; Moura, J. M. S.; da Silva, R.; Yager, P. L.; Keil, R. G.; Richey, J. E. The compositional evolution of dissolved and particulate organic matter along the lower Amazon River-Óbidos to the ocean. Mar. Chem. 2015, 177, 244-256.

(81) Battin, T. J. Dissolved organic matter and its optical properties in a blackwater tributary of the upper Orinoco river, Venezuela. Org. Geochem. 1998, 28, 561-569.

(82) Mladenov, N.; McKnight, D. M.; Macko, S. A.; Norris, M.; Cory, R. M.; Ramberg, L. Chemical characterization of DOM in channels of a seasonal wetland. Aquat. Sci. 2007, 69, 456-471. 
(83) D’Amore, D. V.; Edwards, R. T.; Biles, F. E. Biophysical controls on dissolved organic carbon concentrations of Alaskan coastal temperate rainforest streams. Aquat. Sci. 2016, 78, 381-393.

(84) Gergel, S. E.; Turner, M. G.; Kratz, T. K. Dissolved organic carbon as an indicator of the scale of watershed influence on lakes and rivers. Ecol. Appl. 1999, 9, 1377-1390.

(85) Hanley, K. W.; Wollheim, W. M.; Salisbury, J.; Huntington, T.; Aiken, G. Controls on dissolved organic carbon quantity and chemical character in temperate rivers of North America. Global Biogeochem. Cycles 2013, 27, 492-504.

(86) Duan, S.; He, Y.; Kaushal, S. S.; Bianchi, T. S.; Ward, N. D.; Guo, L. Impact of Wetland Decline on Decreasing Dissolved Organic Carbon Concentrations along the Mississippi River Continuum. Front. Mar. Sci. 2017, 3, No. 280.

(87) Kellerman, A. M.; Dittmar, T.; Kothawala, D. N.; Tranvik, L. J. Chemodiversity of dissolved organic matter in lakes driven by climate and hydrology. Nat. Commun. 2014, 5, No. 3804.

(88) Spencer, R. G. M.; Hernes, P. J.; Ruf, R.; Baker, A.; Dyda, R. Y.; Stubbins, A.; Six, J. Temporal controls on dissolved organic matter and lignin biogeochemistry in a pristine tropical river, Democratic Republic of Congo. J. Geophys. Res.: Biogeosci. 2010, 115, No. G03013.

(89) Inamdar, S.; Singh, S.; Dutta, S.; Levia, D.; Mitchell, M.; Scott, D.; Bais, H.; McHale, P. Fluorescence characteristics and sources of dissolved organic matter for stream water during storm events in a forested mid-Atlantic watershed. J. Geophys. Res.: Biogeosci. 2011, 116, No. G03043.

(90) Fellman, J. B.; Hood, E.; Edwards, R. T.; D’Amore, D. V. Changes in the concentration, biodegradability, and fluorescent properties of dissolved organic matter during stormflows in coastal temperate watersheds. J. Geophys. Res.: Biogeosci. 2009, 114, No. G01021.

(91) Yamashita, Y.; Maie, N.; Briceño, H.; Jaffé, R. Optical characterization of dissolved organic matter in tropical rivers of the Guayana Shield, Venezuela. J. Geophys. Res.: Biogeosci. 2010, 115, No. G00F10.

(92) Maavara, T.; Lauerwald, R.; Regnier, P.; Van Cappellen, P. Global perturbation of organic carbon cycling by river damming. Nat. Commun. 2017, 8, No. 15347.

(93) Monteith, D. T.; Stoddard, J. L.; Evans, C. D.; de Wit, H. A.; Forsius, M.; Høgåsen, T.; Wilander, A.; Skjelkvåle, B. L.; Jeffries, D. S.; Vuorenmaa, J.; Keller, B.; Kopácek, J.; Vesely, J. Dissolved organic carbon trends resulting from changes in atmospheric deposition chemistry. Nature 2007, 450, 537-540.

(94) Roebuck, J. A.; Medeiros, P. M.; Letourneau, M. L.; Jaffe, R. Hydrological Controls on the Seasonal Variability of Dissolved and Particulate Black Carbon in the Altamaha River, GA. J. Geophys. Res.: Biogeosci. 2018, 123, 3055-3071.

(95) Medeiros, P. M.; Babcock-Adams, L.; Seidel, M.; Castelao, R. M.; Di Iorio, D.; Hollibaugh, J. T.; Dittmar, T. Export of terrigenous dissolved organic matter in a broad continental shelf. Limnol. Oceanogr. 2017, 62, 1718-1731. 